DR. MIGUEL LOZANO (Orcid ID : 0000-0003-2593-833X)

DR. PAOLA MARIA MANZINI (Orcid ID : 0000-0002-0385-9123)

DR. RATTI RAM SHARMA (Orcid ID : 0000-0002-7415-4665)

-

DR. AGNETA WIKMAN (Orcid ID : 0000-0002-8810-7974)

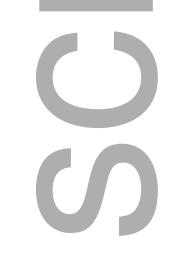

Article type : International Forum

Vox Sanguinis International Forum on Pediatric Indications for Blood Component Transfusion

Mie Topholm Bruun, Kjell Titlestad, Philip C. Spinella, Mark H. Yazer, Miguel Lozano, Meghan Delaney, Hana Lejdarová, Dana Evgenievna Pavlova, Pavel Trakhtman, Nikolay Starostin, Eugene Zhiburt, Marian G.J. van Kraaij, Elise Huisman, Jose M. Kutner, Araci M. Sakashita, Ana P. H. Yokoyama, Josune Zubicaray, Julián Sevilla, Hitoshi Okazaki, Mitsuteru Hiwatari, Yutaka Nagura, Paola Maria Manzini, Giuseppina Facco, Costantino Avdis, Lakhvinder Singh, Rekha Hans, Ratti Ram Sharma, Praveen Kumar, Agneta Wikman, Emöke Deschmann, Hartirathpal Kaur, Joyce Lam Ching Mei, Selina Ho Kah Ying, Koh Pei Lin, Helen V. New, Rachel Moss, Anne Kinmonth, Mary Comande, Helen Savoia, Gemma Crighton, Joanne Yacobovich, Vered Yahalom \& Wendy Lau

\title{
Introduction
}

Blood transfusions have in recent years become increasingly evidence based, at least for adult patients. Implementing transfusion strategies based on the most recent evidence, and utilizing other principles of Patient

This is the author manuscript accepted for publication and has undergone full peer review but has not been through the copyediting, typesetting, pagination and proofreading process, which may lead to differences between this version and the Version of Record. Please cite this article as doi: $\underline{10.1111 / \text { VOX.12763 }}$

This article is protected by copyright. All rights reserved 
Blood Management such as using pharmaceuticals to optimize the hemoglobin concentration of pre-operative patients, and to enhance coagulation, are now commonplace in many hospitals worldwide [1-3]. Most of the research on transfusion strategies has been undertaken in adult patients, however several randomized studies during the past decades have also investigated red blood cell (RBC) transfusion thresholds for pediatric patients[4-6], and evidence that a restrictive hemoglobin threshold for RBC transfusion is safe for different groups of pediatric patients is growing $[6,7]$. Another reason to employ restrictive RBC transfusion thresholds is that fewer transfusions will necessarily lead to a lower number of adverse reactions, which in children has been shown to be high $[8,9]$. Additionally, a recent review concluded that transfusion decisions for pediatric patients should involve consideration of the potential risks, benefits, and strategies that might serve to reduce transfusion requirements[10]. The optimal transfusion strategy for different pediatric patients with different diseases still needs to be confirmed in high-quality studies.

Given the increasing attention being paid to pediatric transfusion issues, the time is now propitious to conduct a Vox Sanguinis International Forum on current pediatric transfusion practice. The main aim of this International Forum was to assess the variability in the current pediatric transfusion practices around the world. The insight gained from this survey can be used as a basis to implement pediatric transfusion guidelines and for benchmarking between comparable hospitals. The participants in the survey were selected from diverse parts of the world in an attempt to reflect a wide variety of practices.

\section{Summary of responses}

\section{Hospital and transfusion service demographics:}

Sixteen hospitals and one blood center (that responded on behalf of three different hospitals) from fifteen different countries participated in the survey (table 1). Countries from North America, South America, Asia, Australia and Europe were represented. Some of the demographics of the hospitals and transfusion services blood center are listed in table 1. Except for one of the Russian hospitals, all hospitals were academic hospitals and the blood center served academic hospitals. Approximately half of the participants had a hospital based blood collection facility while half of the hospitals received blood from a blood collector that was not located at the hospital. Eight hospitals were pediatric specialty hospitals and nine treated both pediatric and adult patients. Most hospitals defined the neonatal period as being less than 28 days/one month old, while The American and Canadian hospitals defined neonates as less than 4 months old. Pediatrics was defined as below 18 years old in most places, while the Indian and Japanese participants defined pediatric patients as below 13 or 15 years old, respectively. The number of pediatric inpatient beds ranged from 20 to 574 beds. Eleven hospitals provided the fullest range of pediatric specialties including Allergy, Immunology and Rheumatology, Cardiology, 
Emergency Medicine, Endocrinology, Gastroenterology, Genetics and Metabolism, General Pediatrics and Adolescent Medicine, Hematology-Oncology, Infectious Diseases, Intensive care (neonatal and/or pediatric), Nephrology, Pulmonology, Surgery of any kind, Trauma care, Otolaryngology, and Palliative Care. Four hospitals provided twelve to fourteen of these specialties, and the Russian National Centre for Pediatric Hematology, Oncology and Immunology provided only Hematology-Oncology, Immunology, Genetics, Intensive care and surgery. The number of pediatric RBC transfusions ranged from 12,144 units that were administered at the Indian participant's hospital (286 beds) to 651 units that were administered at one of the Moscow participant's hospital (574 beds). In all but two of the sixteen hospitals that provided the number of pediatric transfusions, most of the components that were transfused were RBCs, followed by platelets, and then plasma units. In the Children's City Clinical Hospital of St. Vladimir of the Department in Moscow (this hospital does not provide hematology and oncology services) almost three times as many plasma units compared to RBC units were transfused, and very few platelets were transfused. The Russian National Centre for Pediatric Hematology, Oncology and Immunology transfused mainly platelets. Some of these differences are probably explained by the nature of the hospitals since hematology and oncology patients consume more platelets than other pediatric groups $[5,11]$. Eight hospitals were able to determine the number of RBCs transfused according to pediatric age categories including < 1 months old, 1-4 months old and older than 4 months (table 2). All of these hospitals transfused most components to patients who were older than 4 months, but there were large differences in the proportion of RBCs transfused to those patients who were $<4$ months old. At the Indian hospital almost half of RBCs (3894/8250, 47.2\%) were transfused to patients who were less than 4 months old, and one third $(2754,33,4 \%)$ were transfused to neonates (defined locally as < one month old), while at the Russian National Centre for Pediatric Hematology, Oncology and Immunology only 5 percent (308/5692) of RBCs were transfused to patients who were less than 4 months old. Also plasma and platelet components were primarily transfused to children who were more than 4 months, except in Brazil where 45/86 (52.3\%) of the plasma components were transfused to patients who were less than 4 months old.

\section{Transfusion Indications for pediatric and neonatal patients.}

1) Does your country have national guidelines or policies specific for neonatal and/or pediatric transfusions? If yes - do they differ from adult guidelines and if so, how do they differ?

National guidelines or policies specific for neonatal and/or pediatric transfusions existed in nine of the fifteen countries. With the exception of the hospitals in those nine countries, the hospital in Israel had national guidelines for pediatric platelet transfusions and in the hospital in the Czech Republic followed the recommendations in their national guidelines about intrauterine or intrauterine transfusions and doses for children.

This article is protected by copyright. All rights reserved 
2) Does your hospital have local guidelines or policies specific for neonatal and/or pediatric transfusions? If yes - do they differ from adult guidelines and if so, how do they differ?

Sixteen hospitals have local guidelines or policies specific for neonatal and/or pediatric transfusions. The hospitals in Russia-III, Japan and the Netherlands follow the national guidelines.

3) Does your hospital have a list of indications for ordering RBC/plasma/platelets? If yes - list the indications for these products for both pediatrics and neonates, if applicable

Fifteen of the nineteen hospitals (including the three hospitals in Singapore) have a list of indications for ordering blood products. The respondents from the Czech Republic, one of the Russian hospitals, Japan and Sweden did not have indications for ordering blood products.

4) Is it mandatory for the person ordering the transfusion to provide the indication for the transfusion at the time that the blood products are ordered? If yes - is the indication entered electronically?

At thirteen hospitals it is mandatory for the person ordering the transfusion to provide the indication for the transfusion at the time that the blood products are ordered, and in ten of these hospitals it is entered electronically.

5) Is it mandatory for the person ordering the transfusion to provide the patient's diagnosis when blood products are ordered?

It is mandatory for the person ordering the transfusion to provide the patient's diagnosis at seven hospitals.

6) Does your hospital have thresholds for RBC transfusion? If yes, please list the thresholds for both pediatrics and neonates, if applicable.

Most hospitals transfuse hemodynamically stable pediatric patients at hemoglobin less than $7 \mathrm{~g} / \mathrm{dl}$ or 7.5 $\mathrm{g} / \mathrm{dl}$. Only the participants at three hospitals (the Netherlands, Israel and Brazil) employed lower thresholds and no hospitals had higher thresholds for this group of patients. In the hospital in the Netherlands a hemoglobin transfusion threshold of 5.6-6.4 g/dl (3.5-4.0 mmol/L) for stable children is used. Thresholds for non-stable patients or patients who are experiencing symptoms from their anemia are in general higher and differ according to indication and diagnosis. For example the hospital in Spain used a threshold of less than $13 \mathrm{~g} / \mathrm{dl}$ for children with severe pulmonary disease, cyanotic cardiopathy or oxygenation with extracorporeal membrane with descent of oxygen saturation. Hemoglobin thresholds for neonatal patients are in general higher than thresholds for the general pediatric patients, and also differ according to indication and between locations. The hospital in Sweden's thresholds for neonates differs from less than $120 \mathrm{~g} / \mathrm{dl}$ to $85 \mathrm{~g} / \mathrm{dl}$ according to patient's age and respiratory status.

7) Does your hospital have thresholds for platelet transfusion? If yes, please list the thresholds for both pediatrics and neonates, if applicable 
A platelet count of less than $10 \times 10^{\wedge} 9 / \mathrm{L}$ is an absolute indication for platelet transfusion for pediatric patients at most of the participating hospitals, while less than $20 \times 10^{\wedge} 9 / \mathrm{L}$ is an absolute indication for most neonates. For patients with other indications for platelet transfusions, for instance sepsis, active bleedings, planned surgery or CNS bleedings, the thresholds were higher. Some examples include the recommendation to transfuse at a threshold of less than $50 \times 10^{\wedge} 9 / \mathrm{L}$ before an invasive procedure at the hospitals in Spain, Brazil, the Netherlands, Italy and Australia, and a threshold of less than 100x10^9/L before a neurosurgical procedure are specified at ten of the hospitals.

8) Does your hospital have thresholds for plasma transfusion? If yes, please list the thresholds for both pediatrics and neonates, if applicable

Plasma transfusions in general seem to be more dependent on the diagnosis than on INR or clotting factor thresholds, although some hospitals, especially the hospitals in Brazil, Italy, India and Singapore do have several coagulation factor based thresholds for plasma transfusions. For example at the hospital in Brazil a fibrinogen level of less than $1 \mathrm{~g} / \mathrm{L}$ before surgery with a significant risk of bleeding is an indication for plasma transfusion, and at the hospital in India plasma transfusion is indicated for critically ill patients with coagulopathy associated with active bleed and International Normalized Ratio (INR) greater than 1.5.

\section{Product manipulations for pediatric and neonatal patients.}

1) Does your transfusion department offer irradiated products? If yes, what are the indications for irradiation? All of the respondents, except one of the hospitals in Russia (Russia-I), offer irradiated products. At the participating hospitals in USA, Russia-II and Japan all RBCs and platelets are irradiated. The Australian participant uses universal blood product irradiation for patients admitted to specific units (intensive care, neonatal, oncology). All other hospitals offer irradiated products for specific clinical indications, typically intrauterine and exchange transfusions, preterm/neonatal patients, HLA-compatible transfusions, and immune-compromised patients (immune deficiencies, transplantations, medication).

2) Does your transfusion department offer leukodepleted RBCs? If yes, what are the indications for leukodepletion?

Universal leucodepletion of all blood components is done at all centers except at the participating hospitals in Brazil, Singapore, Israel, and India. At these hospitals leucodepletion is done by clinical indication, especially where CMV negative components are required and for patients who previously experienced a febrile non-hemolytic transfusion reaction.

3) Does your transfusion department offer washed RBCs? If yes, what are the indications for washing RBCs? All but one of the Russian hospitals offer washed RBCs. Typically this manipulation is performed for patients with IgA deficiency and patients with severe allergic reactions to previous red cell transfusions. 
4) Does your transfusion department maintain a stock of thawed plasma units for immediate issue? If yes, how many units are kept thawed and what is their ABO group?

Sweden (4 AB units in blood bank, 4 in trauma), UK (1 unit AB plasma), Israel (2 units of all AB0 types) and Australia (2 AB units) maintain a stock of thawed plasma units for immediate issue from their hospital's blood bank. All of the other centers do not maintain thawed plasma.

5) Does your transfusion department offer pathogen inactivated blood products? If yes, which pathogen inactivated products are offered and which pathogen inactivation technologies are employed?

Six hospitals offer pathogen inactivated plasma products; two of the Russian hospitals, and the hospitals in Sweden and Spain, also offer pathogen inactivated platelets. The hospitals in Sweden, Italy and United Kingdom uses solvent/detergent treated plasma for transfusions, the hospitals in Spain and Russia-III uses methylene blue treatment and the hospital in Russia-II uses riboflavin. Platelets at the hospitals in Spain and Russia-III are inactivated by amotosalen.

6) Does your transfusion department prophylactically match RBC blood group antigens other than ABO and RhD for pediatric patients? If yes - which antigens and for which patient categories?

Besides Japan and Singapore all transfusion departments prophylactically match RBC blood group antigens other than $\mathrm{ABO}$ and $\mathrm{RhD}$ for specific groups of pediatric patients (table 3). At some locations all RBCs are matched and some places match RBCs for all girls. For example in the hospital in Italy, all RBCs for neonates and pediatric patients are matched for the $\mathrm{C}, \mathrm{c}, \mathrm{E}, \mathrm{e}$, and $\mathrm{K}$ antigens. At most places the degree of matching depends on the patient's diagnosis. Patients who usually get matched RBCs include patients with chronic transfusion needs, for example patients with hemoglobinopathies and hematological diseases, and patients who have formed a red cell alloantibody. Most places match for $\mathrm{Rh}$ and $\mathrm{K}$, while others include Jk, Fy and MNS antigens in their matching strategy. As another example, RBCs for children with hemoglobiopathies at the hospitals in the Netherlands and Brazil are matched for the Rh, K, Jk, Fy and MNS antigens.

7) Does your transfusion department provide other specific tests for pediatric patients (for example CMVtesting)?

Eight of the hospitals provide CMV negative cellular blood components on specific (rare) indications. Most hospitals consider leukodepletion sufficient for CMV prophylaxis.

8) Does your transfusion department have procedures to minimize the number of donors the patients are exposed to? If yes, please elaborate the procedures?

Eleven of the participating hospitals have procedures to minimize the number of donors to which patients are exposed. All of these hospitals use small-volume splits of large RBC units and store them for the same 
patient. Four hospitals also preferably use apheresis platelets instead of pools of whole blood derived platelets.

9) Does your hospital have a policy to minimize the volume and frequency of the samples drawn for laboratory testing such as using small volume test tubes for collecting samples?

Fifteen hospitals also have a strategy to minimize the volume and frequency of the samples drawn from each patient for laboratory testing, by using small test tubes and only taking the minimum volume needed to perform the test. Many hospitals also focus on minimizing the frequency of obtaining blood samples, and one of the hospitals in Singapore also focuses on transcutaneous measurements of blood gases and bilirubin to avoid drawing blood samples.

10) Does your transfusion department have a policy for the maximum storage age of RBCs that can be issued to specific patients? If yes, please state the policy

The maximum storage age of RBCs varies (table 3). Many centers use the freshest RBCs for intrauterine transfusions, exchange transfusions and pre-term/neonatal transfusions. The maximum storage times for these patients varies from 3 days at one of the hospitals in Singapore to 5, 7 or 10 days at many centers. Three hospitals also keep a maximum storage time of 24 hours post irradiation for specific groups, inclusive liver transplanted patients, exchange transfusions, intrauterine transfusions, prime blood and neonatal cardiac patients.

\section{Blood product dosing:}

1) What dose of RBCs/platelets/plasma is usually prescribed for stable pediatric and/or neonatal patients (milliliters/kg or dose of unit)?

The doses vary between 5 to $20 \mathrm{ml} / \mathrm{kg}$ for $\mathrm{RBC}$ and platelets and between 10 to $20 \mathrm{ml} / \mathrm{kg}$ for plasma.

\section{Discussion}

With the exception of one respondent, the hospitals that participated in this international forum provided a similar range of pediatric services, which makes it meaningful to compare practices at the hospitals. The survey found that current pediatric transfusion practices varies around the world, and highlights areas of variability. All of the hospitals had some guidelines for pediatric transfusions, some were very detailed and some more general. All hospitals had employed restrictive transfusion triggers of $7.5 \mathrm{~g} / \mathrm{dl}$ or less for stable patients, and in the Netherlands the thresholds for some stable patients were as low as $5.6 \mathrm{~g} / \mathrm{dl}(3.5 \mathrm{mmol} / \mathrm{L})$. Interesting differences in the manipulation of blood products included universal irradiation of all RBCs and platelets in USA, Russia-II and Japan, while some hospitals only irradiated their products for limited indications. Thawed plasma for immediate issue were only offered at four the hospitals, and pathogen inactivation at six hospitals. 


\section{References}

1 Murphy MF, Goodnough LT: The scientific basis for patient blood management. Transfus Clin Biol 2015; 22: 90-6.

2 Bruun MT, Pendry K, Georgsen J, et al.: Patient Blood Management in Europe: surveys on top indications for red blood cell use and Patient Blood Management organization and activities in seven European university hospitals. Vox sanguinis 2016; 111: 391-8.

3 M. T. Bruun JG, K. Titlestad, M. Yazer, M. F. Murphy: Patient Blood Management - from local initiatives to European collaborations. ISBT Science Series 2017; 12 435-40.

4 Fergusson DA, Hebert P, Hogan DL, et al.: Effect of fresh red blood cell transfusions on clinical outcomes in premature, very low-birth-weight infants: the ARIPI randomized trial. JAMA 2012; 308: 1443-51.

5 Couban S, Carruthers J, Andreou P, et al.: Platelet transfusions in children: results of a randomized, prospective, crossover trial of plasma removal and a prospective audit of WBC reduction. Transfusion 2002; 42: 753-8.

6 de Gast-Bakker DH, de Wilde RB, Hazekamp MG, et al.: Safety and effects of two red blood cell transfusion strategies in pediatric cardiac surgery patients: a randomized controlled trial. Intensive Care Med 2013; 39: 2011-9.

7 Lacroix J, Hebert PC, Hutchison JS, et al.: Transfusion strategies for patients in pediatric intensive care units. N Engl J Med 2007; 356: 1609-19.

8 Pedrosa AK, Pinto FJ, Lins LD, et al.: Blood transfusion reactions in children: associated factors. $J$ Pediatr (Rio J) 2013; 89: 400-6.

9 Stainsby D, Jones H, Wells AW, et al.: Adverse outcomes of blood transfusion in children: analysis of UK reports to the serious hazards of transfusion scheme 1996-2005. Br J Haematol 2008; 141: 73-9.

10 Istaphanous GK, Wheeler DS, Lisco SJ, et al.: Red blood cell transfusion in critically ill children: a narrative review. Pediatr Crit Care Med 2011; 12: 174-83.

11 Saluja K, Thakral B, Marwaha N, et al.: Platelet audit: Assessment and utilization of this precious resource from a tertiary care hospital. Asian journal of transfusion science 2007; 1: 8-11.

Mie Topholm Bruun

Department of Clinical Immunology 
Odense University Hospital

J.B. Winsløws Vej 4

DK-5000 Odense C

Denmark

Telephone: +4565413576

Email: Mie.Topholm.Bruun@rsyd.dk

Kjell Titlestad

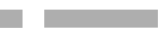

Department of Clinical Immunology

Odense University Hospital

J.B. Winsløws Vej 4

DK-5000 Odense C

Denmark

Telephone: +4565413675

Email: kjell.titlestad@rsyd.dk

Philip C. Spinella

Department of Pediatrics

Division of Critical Care Medicine

Washington University in St Louis

St Louis, MO, USA

Phone: +1 314 286-0858

Email: pspinella@wustl.edu

Mark H. Yazer, MD

The Institute for Transfusion Medicine

3636 Blvd of the Allies

Pittsburgh PA 15143 USA

Phone: 412 209-7522

Fax: 412 209-5826

Email: myazer@itxm.org

Miguel Lozano

This article is protected by copyright. All rights reserved 
Department of Hemotherapy and Hemostasis

Hospital Clinic

Villaroel 170

Barcelona 08036 Spain

Phone: +34932275448

Email:mlozano@clinic.cat
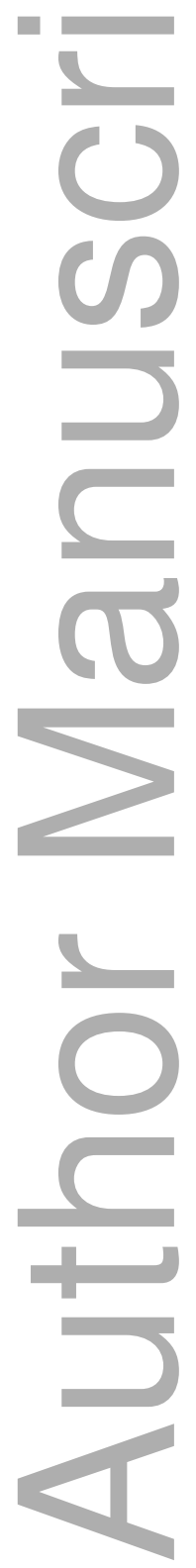

This article is protected by copyright. All rights reserved 
Table 1. Demographics and details of the survey responses from the participants.

\begin{tabular}{|c|c|c|c|c|c|c|c|c|c|c|c|c|c|c|c|c|c|}
\hline $\begin{array}{l}\text { Country } \\
-\end{array}$ & $\begin{array}{l}\text { United } \\
\text { States of } \\
\text { America }\end{array}$ & $\begin{array}{c}\text { Czech } \\
\text { Republic }\end{array}$ & Russia-I & Russia-II & $\begin{array}{c}\text { Russia- } \\
\text { III }\end{array}$ & Netherlands & Brazil & Spain & Japan & Italy & India & Sweden & Singapore & $\begin{array}{l}\text { United } \\
\text { Kingdom }\end{array}$ & Israel & Australia & Canada \\
\hline City & $\begin{array}{l}\text { Washington } \\
\text { D.C. }\end{array}$ & Brno & Moscow & Moscow & Moscow & Rotterdam & $\begin{array}{c}\text { São } \\
\text { Paulo }\end{array}$ & Madrid & Tokyo & Torino & Chandigarh & Stockholm & $\begin{array}{l}\text { Singapore } \\
(3 \\
\text { hospitals) }\end{array}$ & London & Petah Tiqva & Parkville & Toronto \\
\hline $\begin{array}{c}\text { Is the hospital a } \\
\text { teaching/academic } \\
\text { hospital }\end{array}$ & Yes & Yes & No & Yes & Yes & Yes & Yes & Yes & Yes & Yes & Yes & Yes & Yes & Yes & Yes & Yes & Yes \\
\hline $\begin{array}{l}\text { Do the hospital receive } \\
\text { blood components from } \\
\text { the blood center or are } \\
\text { they collected and } \\
\text { prepared in your own } \\
\text { facility? }\end{array}$ & Both & $\begin{array}{l}\text { In our } \\
\text { own } \\
\text { facility }\end{array}$ & $\begin{array}{l}\text { In our } \\
\text { own } \\
\text { facility }\end{array}$ & $\begin{array}{l}\text { Hospital } \\
\text { based } \\
\text { blood } \\
\text { bank }\end{array}$ & $\begin{array}{l}\text { Blood } \\
\text { Center }\end{array}$ & $\begin{array}{l}\text { Blood } \\
\text { Center }\end{array}$ & $\begin{array}{l}\text { In our } \\
\text { own } \\
\text { facility }\end{array}$ & $\begin{array}{l}\text { Blood } \\
\text { Center }\end{array}$ & $\begin{array}{l}\text { Blood } \\
\text { Center }\end{array}$ & $\begin{array}{l}\text { In our } \\
\text { own } \\
\text { facility }\end{array}$ & $\begin{array}{c}\text { Hospital } \\
\text { based } \\
\text { blood bank }\end{array}$ & $\begin{array}{c}\text { Hospital } \\
\text { based } \\
\text { blood } \\
\text { bank }\end{array}$ & $\begin{array}{l}\text { Blood } \\
\text { Center }\end{array}$ & $\begin{array}{l}\text { Blood } \\
\text { Center }\end{array}$ & $\begin{array}{l}\text { Prepared in } \\
\quad \text { a } \\
\text { neighboring } \\
\text { facility }\end{array}$ & $\begin{array}{l}\text { Blood } \\
\text { Center }\end{array}$ & $\begin{array}{l}\text { Blood } \\
\text { Center }\end{array}$ \\
\hline Neonate definition & $<4$ months & $\begin{array}{c}30 \text { days } \\
\text { old }\end{array}$ & & $\begin{array}{c}<28 \\
\text { days old }\end{array}$ & $\begin{array}{l}<30 \\
\text { days old }\end{array}$ & $\begin{array}{c}<28 \text { days } \\
\text { old. For } \\
\text { transfusion } \\
<3 \text { months }\end{array}$ & $\begin{array}{c}<28 \\
\text { days } \\
\text { old }\end{array}$ & $\begin{array}{l}<30 \\
\text { days } \\
\text { old }\end{array}$ & $\begin{array}{l}<30 \\
\text { days } \\
\text { old }\end{array}$ & $\begin{array}{l}<30 \\
\text { days } \\
\text { old }\end{array}$ & $\begin{array}{c}<30 \text { days } \\
\text { old }\end{array}$ & $\begin{array}{c}<1 \\
\text { month, } \\
\text { corrected } \\
\text { for GA }\end{array}$ & $<1$ month & $\begin{array}{c}<28 \\
\text { days old }\end{array}$ & $\begin{array}{c}<30 \text { days } \\
\text { old }\end{array}$ & $\begin{array}{l}<28 \\
\text { days old }\end{array}$ & $\begin{array}{l}<4 \\
\text { months }\end{array}$ \\
\hline Pediatric definition & $\begin{array}{c}<18 \text { years } \\
\text { old }\end{array}$ & $\begin{array}{c}<19 \\
\text { years } \\
\text { old }\end{array}$ & & $\begin{array}{l}<18 \\
\text { years } \\
\text { old }\end{array}$ & $\begin{array}{l}<18 \\
\text { years } \\
\text { old }\end{array}$ & $\begin{array}{c}<18 \text { years } \\
\text { old }\end{array}$ & $\begin{array}{l}<18 \\
\text { years } \\
\text { old }\end{array}$ & $\begin{array}{l}<18 \\
\text { years } \\
\text { old }\end{array}$ & $\begin{array}{c}<15 \\
\text { years } \\
\text { old }\end{array}$ & $\begin{array}{l}<18 \\
\text { years } \\
\text { old }\end{array}$ & $\begin{array}{c}<13 \text { years } \\
\text { old }\end{array}$ & $\begin{array}{c}<18 \text { years } \\
\text { old }\end{array}$ & $\begin{array}{l}<16 \text { years } \\
\text { old in } \\
\mathrm{KKH}^{*},<18 \\
\text { years old } \\
\text { in } \mathrm{NUH}^{*}\end{array}$ & $\begin{array}{l}<18 \\
\text { years } \\
\text { old }\end{array}$ & $\begin{array}{c}<18 \text { years } \\
\text { old }\end{array}$ & $\begin{array}{l}<18 \\
\text { years } \\
\text { old }\end{array}$ & $\begin{array}{l}<18 \\
\text { years } \\
\text { old }\end{array}$ \\
\hline $\begin{array}{c}\text { Does the hospital } \\
\text { primarily treat pediatric } \\
\text { patients? }\end{array}$ & Yes & No & Yes & Yes & No & No & No & Yes & No & No & No & No & No & Yes & Yes & Yes & Yes \\
\hline $\begin{array}{c}\text { Number of pediatric } \\
\text { inpatient beds }\end{array}$ & 313 & 400 & 574 & 220 & N/A & N/A & 106 & 180 & 20 & 300 & 283 & 212 & $\begin{array}{l}\mathrm{SGH}^{*}: 48, \\
\mathrm{NUH}^{*}: 100\end{array}$ & 350 & 300 & 357 & 350 \\
\hline $\begin{array}{c}R B C \text { units transfused to } \\
\text { pediatric and neonatal } \\
\text { patients per year }\end{array}$ & 8057 & 1671 & 651 & 6000 & N/A & 1468 & 708 & $\begin{array}{l}1800- \\
2000\end{array}$ & 1260 & 3000 & 12144 & 3683 & $\begin{array}{l}\begin{array}{c}4394 \text { (all } \\
\text { of } \\
\text { Singapore) }\end{array} \\
\end{array}$ & 5250 & $>5000$ & 4700 & $\begin{array}{l}8000- \\
8700\end{array}$ \\
\hline $\begin{array}{l}\text { Plasma units transfused } \\
\text { to pediatric and } \\
\text { neonatal patients per } \\
\text { year }\end{array}$ & 1760 & 182 & 1896 & 1700 & N/A & 551 & 86 & $\begin{array}{l}150- \\
250\end{array}$ & 406 & 1300 & 3322 & 1339 & 1063 & 1700 & $>700$ & 2350 & 1500 \\
\hline $\begin{array}{c}\begin{array}{c}\text { Platelet units transfused } \\
\text { to pediatric and } \\
\text { neonatal patients per } \\
\text { year }\end{array} \\
\text { This article is }\end{array}$ & $\begin{array}{l}3525 \text { (Full } \\
\text { size units, } \\
\text { aliquoted to } \\
\text { smaller } \\
\text { prosef) }\end{array}$ & d by & opyr & ht. A & right & reser & 504 & $\begin{array}{l}1300- \\
1500\end{array}$ & 8067 & 2000 & 8282 & 1876 & 2241 & 4457 & $>2150$ & 3200 & $\begin{array}{c}3500- \\
3800\end{array}$ \\
\hline
\end{tabular}




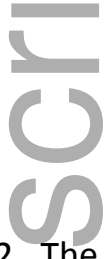

Table 2. The number of blood products transfused to pediatric patients at the hospitals where these data were available.

\begin{tabular}{|c|c|c|c|c|c|c|c|c|}
\hline Country & $\begin{array}{l}\text { Czech } \\
\text { Republic }\end{array}$ & Russia-II & Netherlands & Brazil & Japan & Italy & India & Singapore \\
\hline City & Brno & Moscow & Rotterdam & São Paulo & Tokyo & Torino & Chandigarh & Singapore \\
\hline+2 & & & & & & & & \\
\hline $\begin{array}{l}\text { Total number of RBC units } \\
\text { transfused to pediatric } \\
\text { patients per year }\end{array}$ & 1671 & 6000 & 1468 & 708 & 1260.24 & 3000 & 12144 & 4394 \\
\hline $\begin{array}{l}\text { - Younger than } 1 \\
\text { month }\end{array}$ & 216 & 30 & 31 & 114 & 240.74 & 300 & 2754 & 794 \\
\hline - 1-4 months & 231 & 278 & 50 & 98 & 79.5 & 180 & 1140 & 530 \\
\hline $\begin{array}{l}\text { Older than } 4 \\
\text { months }\end{array}$ & 1224 & 5692 & 1387 & 496 & 940 & 2500 & 8250 & 3070 \\
\hline 1 & & & & & & & & \\
\hline $\begin{array}{l}\text { Total plasma units for } \\
\text { pediatric patients per year }\end{array}$ & 182 & 1700 & 551 & 86 & 406 & 1300 & 3322 & 1063 \\
\hline - $\quad$ Younger than 1 & 24 & 10 & 21 & 28 & 134 & 240 & 715 & 320 \\
\hline
\end{tabular}

This article is protected by copyright. All rights reserved 


\begin{tabular}{|c|c|c|c|c|c|c|c|c|}
\hline month & & & & & & & & \\
\hline - $\quad 1-4$ months & 29 & 104 & 21 & 17 & 40 & 90 & 212 & 106 \\
\hline $\begin{array}{l}\text { - Older than } 4 \\
\text { months }\end{array}$ & 129 & 1586 & 509 & 41 & 232 & 1000 & 2395 & 637 \\
\hline $\begin{array}{l}\text { Total platelet units for } \\
\text { pediatric patients per year }\end{array}$ & 921 & 6300 & 816 & 504 & 8067 & 2000 & 8282 & 2241 \\
\hline $\begin{array}{l}\text { - Younger than } 1 \\
\text { month }\end{array}$ & 40 & 29 & 26 & 58 & 647 & 50 & 2402 & 310 \\
\hline - $\quad$ 1-4 months & 24 & 69 & 19 & 39 & 90 & 15 & 328 & 274 \\
\hline $\begin{array}{l}\text { - Older than } 4 \\
\text { months }\end{array}$ & 857 & 6202 & 771 & 407 & 7330 & 1900 & 5552 & 1656 \\
\hline
\end{tabular}

The number of RBC, plasma and platelet units transfused for pediatric patients in total, patients younger than 1 month, 1-4 months and older than 4 months. Note: Units are defined differently at the various hospitals, hence the relationship between the transfusions for the different categories is the most comparable parameter.

bescription of RBC antigen matching strategies.

\begin{tabular}{|c|c|c|}
\hline Country & $\begin{array}{l}\text { Does your transfusion department prophylactically match RBC blood group antigens other than } \\
A B O \text { and RhD for pediatric patients? If yes - which antigens and for which patient categories? }\end{array}$ & $\begin{array}{l}\text { Does your transfusion department have a policy for the maximum storage age of RBCs that can be } \\
\text { issued to specific patients? If yes, please state the policy }\end{array}$ \\
\hline $\begin{array}{l}\text { United States of } \\
\text { America }\end{array}$ & $\begin{array}{l}\mathrm{SCD}: \mathrm{Rh} / \mathrm{K} \text { matched. Antigen matched cells when a patient has certain serological findings, on the } \\
\text { case-by-case basis. }\end{array}$ & $\begin{array}{l}\text { Neonates, ECMO and cardiac surgery pump prime units: Maximum } 10 \text { days storage (preferable }<7 \\
\text { days storage for cardiac surgery pump prime units). Specific storage time allowed after irradiation. }\end{array}$ \\
\hline Czech Republic & Oncology patients & $\begin{array}{l}\text { Polytraumatic patients: Maximum } 14 \text { days storage. Neonates: Maximum } 5 \text { days storage. Pediatric: } \\
\text { Maximum } 14 \text { days storage. }\end{array}$ \\
\hline Russia-1 & Since 1999, we have been selecting erythrocytes with antigens - A, B, C, CW, C, E, e, K, K. & Children $<1$ month: Maximum 10 days storage. Exchange transfusion: Maximum 5 days storage. \\
\hline Russia-2 & All patients: $\mathrm{k}$ and $\mathrm{Cw}$ matched. & Neonatal patients: Maximum 5 days storage. \\
\hline Russia-3 & $\mathrm{N} / \mathrm{A}$ & No \\
\hline Netherlands & $\begin{array}{l}\text { All girls, patients with MDS and auto-antibodies against red blood cells: cEK matched. } \\
\text { Hemoglobinopathies: cEK, Fy a/b, Jk a/b, MNSs matched. }\end{array}$ & N/A \\
\hline Brazil & $\begin{array}{l}\text { Chronically transfused patients with hereditary hemoglobinopathies and myelodysplastic syndrome: } \\
\mathrm{Rh}, \mathrm{K}, \mathrm{Fy}, \mathrm{Jk} \text {, and MNS matched. }\end{array}$ & Massive transfusion, exchange transfusions, intrauterine transfusion: Maximum 5 days storage. \\
\hline Spain & All girls: Rh and $\mathrm{K}$ matched. & No \\
\hline Japan & No & No \\
\hline
\end{tabular}

This article is protected by copyright. All rights reserved 


\begin{tabular}{|c|c|c|}
\hline Italy & All neonates and pediatric patients: $\mathrm{C}, \mathrm{c}, \mathrm{E}, \mathrm{e}$, and $\mathrm{K}$ matched. & $\begin{array}{l}\text { Patients }<6 \text { months old: Maximum } 5 \text { days storage post-irradiation. Liver transplant, exchange } \\
\text { transfusions, intrauterine transfusions and neonatal cardiac surgery: Maximum } 5 \text { days storage and } 24 \\
\text { hours post-irradiation. }\end{array}$ \\
\hline India & Thalassemia patients: E,e,C,c and K matched. & $\begin{array}{l}\text { Department of transfusion medicine has a policy to reserve RBCs for maximum of } 72 \text { hours for a } \\
\text { particular patient after which it can be released for other patients for optimum usage of the product. }\end{array}$ \\
\hline Sweden $\mathrm{r}$ & Chronic transfusion requirements: Rh, K, Jk, Fy matched. & $\begin{array}{l}\text { Pediatric patients and all who requires chronic transfusions: Maximum } 14 \text { days storage. Exchange } \\
\text { transfusions and prime blood: }<5 \text { days storage, maximum } 24 \text { hours post-irradiation. }\end{array}$ \\
\hline Singapore & No & $\begin{array}{l}\text { SGH: For neonates: Preference }<3 \text { days storage. BSG: Intrauterine transfusion and exchange } \\
\text { transfusion: }<5 \text { days storage. Pediatric ECMO and neonates }<5 \mathrm{~kg} \text { undergoing cardiac surgery: }<7 \text { days } \\
\text { storage. }\end{array}$ \\
\hline United Kingdom & ransfusion dependent patients: Rh matched. Clinically significant antibodies: Rh matched. & $\begin{array}{l}\text { Patients }<1 \text { year requiring large volume neonatal pack transfusions: }<5 \text { days storage. Cardiac surgery } \\
\text { and } S C D:<14 \text { days storage. Irradiated units: }<14 \text { days storage }(<24 \text { hours for specific groups })\end{array}$ \\
\hline Israel & Hemoglobinopathies, AlHA patients & $\begin{array}{l}\text { Exchange transfusion and pre term: }<7 \text { days storage. } \\
\text { Thalassemia and SCD patients: }<10 \text { days storage (up to } 14 \text { if multiple antibodies). }\end{array}$ \\
\hline Australia & $\begin{array}{l}\text { All patients: K neg. Hemoglobinopathies: C, D, E and K matched. Exchange transfusions, WAIHA: } \\
\text { Rh/K, Jka, Fy and Ss matched. Alloantibodies: Extended red cell matching. Intrauterine transfusions, } \\
\text { HDFN: Fya, Jk, M, N and Ss matched. }\end{array}$ & $\begin{array}{l}\text { Exchange transfusion and intrauterine transfusion: }<5 \text { days storage. Cardiac surgery: }<7 \text { days storage. } \\
\text { Massive transfusion: Aim }<10 \text { days storage. Chronically transfused: Aim }<14 \text { days storage. }\end{array}$ \\
\hline Canada & $\begin{array}{l}\text { All girls: K neg. SCD and WAIHA: Rh and K matched. SCD with clinically significant antibodies: Fya, } \\
\text { Jka, Jkb, S matched. }\end{array}$ & $\begin{array}{l}\text { Infants }<3-6 \text { months: }<7 \text { days storage. } 6 \text { months to } 4 \text { years: }<14 \text { days storage. Patients over } 4 \text { years: }< \\
28 \text { days storage. Hemoglobinopathy patients: }<21 \text { days storage. Fresher units for cardiac surgery. }\end{array}$ \\
\hline
\end{tabular}

SGH: Singapore General Hospital, NUH: National University Hospital. AIHA: Autoimmune hemolytic anemia, ECMO: Extracorporeal membrane oxygenation, SCD: Sickle cell disease, WAIHA: Warm autoimmune hemolytic anemia

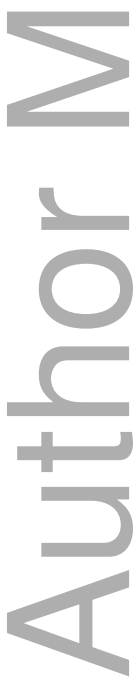

This article is protected by copyright. All rights reserved 


\section{University Library}

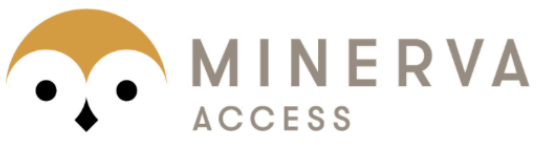

A gateway to Melbourne's research publications

Minerva Access is the Institutional Repository of The University of Melbourne

\section{Author/s:}

Bruun, MT;Yazer, MH;Spinella, PC;Titlestad, K;Lozano, M;Delaney, M;Lejdarová, H;Pavlova, DE;Trakhtman, P;Starostin, N;Zhiburt, E;van Kraaij, MGJ;Huisman, E;Kutner, JM;Sakashita, AM;Yokoyama, APH;Zubicaray, J;Sevilla, J;Okazaki, H;Hiwatari, M;Nagura, Y;Manzini, PM;Facco, G;Avdis, C;Singh, L;Hans, R;Sharma, RR;Kumar, P;Wikman, A;Deschmann, E;Kaur, H;Mei, JLC;Ying, SHK;Pei Lin, K;New, HV;Moss, R;Kinmonth, A;Comande, M;Savoia, $\mathrm{H}$;Crighton, G;Yacobovich, J;Yahalom, V;Lau, W

Title:

Vox Sanguinis International Forum on paediatric indications for blood component transfusion: Summary.

\section{Date:}

2019-07

\section{Citation:}

Bruun, M. T., Yazer, M. H., Spinella, P. C., Titlestad, K., Lozano, M., Delaney, M., Lejdarová, H., Pavlova, D. E., Trakhtman, P., Starostin, N., Zhiburt, E., van Kraaij, M. G. J., Huisman, E., Kutner, J. M., Sakashita, A. M., Yokoyama, A. P. H., Zubicaray, J., Sevilla, J., Okazaki, H. ,... Lau, W. (2019). Vox Sanguinis International Forum on paediatric indications for blood component transfusion: Summary.. Vox Sang, 114 (5), pp.523-530. https://doi.org/10.1111/ vox.12763.

Persistent Link:

http://hdl.handle.net/11343/285861 